\title{
ANALISIS PENGARUH FAKTOR -FAKTOR TOTAL QUALITY MANAGEMENT (TQM) TERHADAP KINERJA PERUSAHAAN PT XYZ
}

\author{
Vania Novianty \\ Program Studi Magister Manajemen Universitas Tarumanagara \\ vania.novianty@gmail.com
}

\begin{abstract}
This research was conducted at PT XYZ, a national construction company that offers design and construction services. The condition of PT XYZ is still weak in terms of company's performance such as inefficient management, limited fund, technological limitations, tools, methods, and low quality human resources. Therefore, it is necessary to select a management system that can help the company to maintain product quality and improve company's performance. This paper identifies management system decision that may assist company to maintain product quality and increase company's performance for example Total Quality Management (TQM).

TQM consist of six dimensions of leadership, strategic planning, customer focus, use of information and analysis, human resource management, and process management. The methods of data collection were conducted through interview and questionnaires. The samples used in this research are 185 employees, however valid usable data submitted were 176 data. The analysis uses multiple regression method on Statistical Package Social Science (SPSS) software as its single processing tool. The results show that leadership, customer focus, human resource management, and process management were significantly influence company's performance, but strategic planning and usage of information and analysis were not significantly influence company's performance.
\end{abstract}

Keywords: Total Quality Management, Leadership, Strategic Planning, Customer Focus, Use of Information and Analysis, Human Resource Management,Process Management, Company's Performance.

\section{PENDAHULUAN}

Industri konstruksi merupakan salah satu komponen penting dalam perekonomian bangsa, dimana konstribusi industri konstruksi akan meningkat sejalan dengan kemajuan perekonomian bangsa. Bila dilihat dari jumlah kontraktor yang cukup banyak sedangkan ruang lingkup pekerjaan yang ditawarkan terbatas, menimbulkan persaingan antara sesama kontraktor. Penelitian dilakukan pada PT XYZ, yaitu sebuah perusahaan kontraktor nasional yang menawarkan jasa desain dan pelaksanaan konstruksi. Kondisi PT XYZ saat ini masih lemah dalam kinerja perusahaan seperti manajemen yang tidak efisien, keterbatasan dana, keterbatasan dalam teknologi, peralatan dan metode, dan sumber daya manusia yang kurang berkualitas. Permasalahan-permasalahan yang terjadi di PT XYZ dapat mengakibatkan hasil akhir dari pelaksanaan konstruksi sering menyimpang dari perencanaan awal.

Oleh karena itu, diperlukan pemilihan sistem manajemen yang dapat membantu perusahaan untuk menjaga kualitas produk dan meningkatkan kinerja perusahaan. Menurut M. Nasution (2005 :43), perusahaan yang menerapkan TQM akan memperoleh beberapa manfaat utama yang pada akhirnya akan meningkatkan laba serta daya saing perusahaan yang bersangkutan. Penelitian ini bertujuan untuk menganalisis pengaruh antara faktor- faktor TQM dengan kinerja Perusahaan menggunakan enam dimensi TQM yaitu kepemimpinan, perencanaan strategik, fokus pada pelanggan, penggunaan informasi dan analisa, manajemen SDM, dan proses manajemen yang diadopsi dari Samson dan Terziovski (1999) karena dimensi yang mereka gunakan telah lulus uji dan sesuai dengan kriteria yang dikeluarkan 
oleh Malcolm Baldrige National Quality Award (MBNQA), yang merupakan sejenis penghargaan tahunan yang diberikan oleh pemerintah Amerika Serikat (melalui Department of Commerce) kepada setiap organisasi di negara USA - baik profit dan non profit - yang dianggap mencapai kinerja yang unggul.

\section{TUJUAN PENELITIAN}

Berdasarkan identifikasi masalah yang telah disebutkan sebelumnya, maka tujuan penelitian adalah.

1. Untuk mengetahui pengaruh kepemimpinan terhadap kinerja perusahaan

2. Untuk mengetahui pengaruh perencanaan strategik terhadap kinerja perusahaan

3. Untuk mengetahui pengaruh fokus pada pelanggan terhadap kinerja perusahaan

4. Untuk mengetahui pengaruh penggunaan informasi dan analisa terhadap kinerja perusahaan

5. Untuk mengetahui pengaruh manajemen SDM terhadap kinerja perusahaan

6. Untuk mengetahui pengaruh manajemen proses terhadap kinerja perusahaan

\section{TINJAUAN PUSTAKA}

Menurut Rudianto (2006), Kinerja perusahaan adalah kemampuan perusahaan untuk mengelola seluruh sumber daya yang dimiliki perusahaan dalam rangka memperoleh laba usaha dalam jangka pendek dan jangka panjang

Menurut Tjiptono dan Diana (2012), TQM merupakan pendekatan dalam meningkatkan produktivitas organisasi (kinerja kuantitatif) meningkatkan kualitas (menurunkan kesalahan dan tingkat kerusakan), meningkatkan efektifitas pada semua kegiatan, meningkatkan efisiensi (menurunkan sumberdaya melalui peningkatan produktivitas), dan mengerjakan segala sesuatu yang benar dengan cara yang tepat. Dalam berbagai literatur manajemen strategi diketahui bahwa perusahaan diseluruh dunia telah menerapkan Total Quality Management (TQM) selama beberapa dekade terakhir.

Metode yang dapat digunakan dalam melakukan pengukuran kinerja diantaranya Malcolm Baldrige Criteria for Performance Excellence (MBCfPE) dapat membantu perusahaan atau organisasi dalam memperbaiki kinerjanya untuk mencapai level kinerja ekselen. Kriteria yang digunakan untuk menilai suatu performa applicant adalah kepemimpinan, perencanaan strategis, fokus pada pelanggan, penggunaan informasi dan analisa, manajemen SDM dan manajemen proses.

Robbins (1991) mendefinisikan kepemimpinan sebagai kemampuan untuk mempengaruhi sekelompok anggota agar bekerja mencapai tujuan dan sasaran yang ditetapkan. Kepemimpinan penting dalam mempengaruhi karyawan, efektifitas, dan efisien sumber daya serta kepemimpinan yang efektif mengarahkan strategi perusahaan untuk mencapai kepuasan pelanggan dan hasil bisnis (Jaafreh dan Abedalfattah, 2013). Kepemimpinan manajemen berperan dalam meningkatkan kinerja bisnis perusahaan dengan menghadirkan visi dan misi perusahaan, dorongan terhadap perubahan, dan penggunaan ideide (Samson dan Mile, 1999).

Perencanaan strategik secara eksplisit berhubungan dengan manajemen perubahan dan kinerja perusahaan, hal ini telah menjadi hasil penelitian beberapa ahli (e.g., Ansoff, 1965; Anthony,1965; Lorange, 1980; Steiner, 1979). Lorange (1980), menuliskan, bahwa strategic planning adalah kegiatan yang mencakup serangkaian proses dari inovasi dan merubah perusahaan.

Fokus terhadap pelanggan digunakan untuk mencari kebutuhan yang diinginkan pelanggan. Upaya fokus pada pelanggan dapat membuat produk perusahaan sesuai dengan kebutuhan dan keinginan pelanggan serta meminimalisasi komplain dari pelanggan (Sadikoglu dan Hilal, 2014). Jika hal ini tidak dilakukan perusahaan dapat kehilangan potensi pasar yang belum dimanfaatkan (Prajogo, 2004). Fokus pada pelanggan menjadikan 
perusahaan lebih memahami pasar dan kebutuhan pelanggan, dengan memenuhi kebutuhan ini perusahaan dapat meningkatkan kinerja (Hassan et al, 2013).

(Saraph et al, 1989) menuturkan bahwa informasi dan analisis kualitas berguna untuk kerja sama diantara karyawan dan manajer sebagai pemecahan masalah pengukuran kualitas serta evaluasi kinerja kualitas perusahaan. Informasi dan analisis memberikan pengukuran yang efektif dalam meningkatkan kinerja organisasi (Hassan et al, 2013). Informasi dan analisis memiliki pengaruh secara positif dan signifikan baik itu praktek dan pentingnya terhadap kinerja bisnis (Ahmad, 2013). Analisis informasi data yang dikumpulkan dapat digunakan untuk memecahkan masalah yang ada sehingga menjaga kualitas (Flynn, 1994).

Menurut Jaafreh \& Al-abedallat (2012:97) sumber daya manusia meliputi pelatihan karyawan dan hubungan karyawan yang memiliki hubungan positif dengan peningkatan kinerja organisasi.

Manajemen proses berfokus pada pengelolaan proses manufaktur sehingga beroperasi seperti yang diharapkan, tanpa kerusakan, bahan yang hilang, perlengkapan, peralatan, dan kemampuan tenaga kerja. Peningkatan proses meningkatkan keseragaman output produk, mengurangi kesalahan, dan mengurangi pemborosan. Manajemen proses mengacu pada kombinasi dari mesin, metode, bahan, alat, dan orang yang bekerja dalam produksi (Jaafreh dan Abedalfattah, 2013).

\section{Kerangka Teori dan Hipotesis}

\section{Gambar 1 \\ Kerangka Teori}

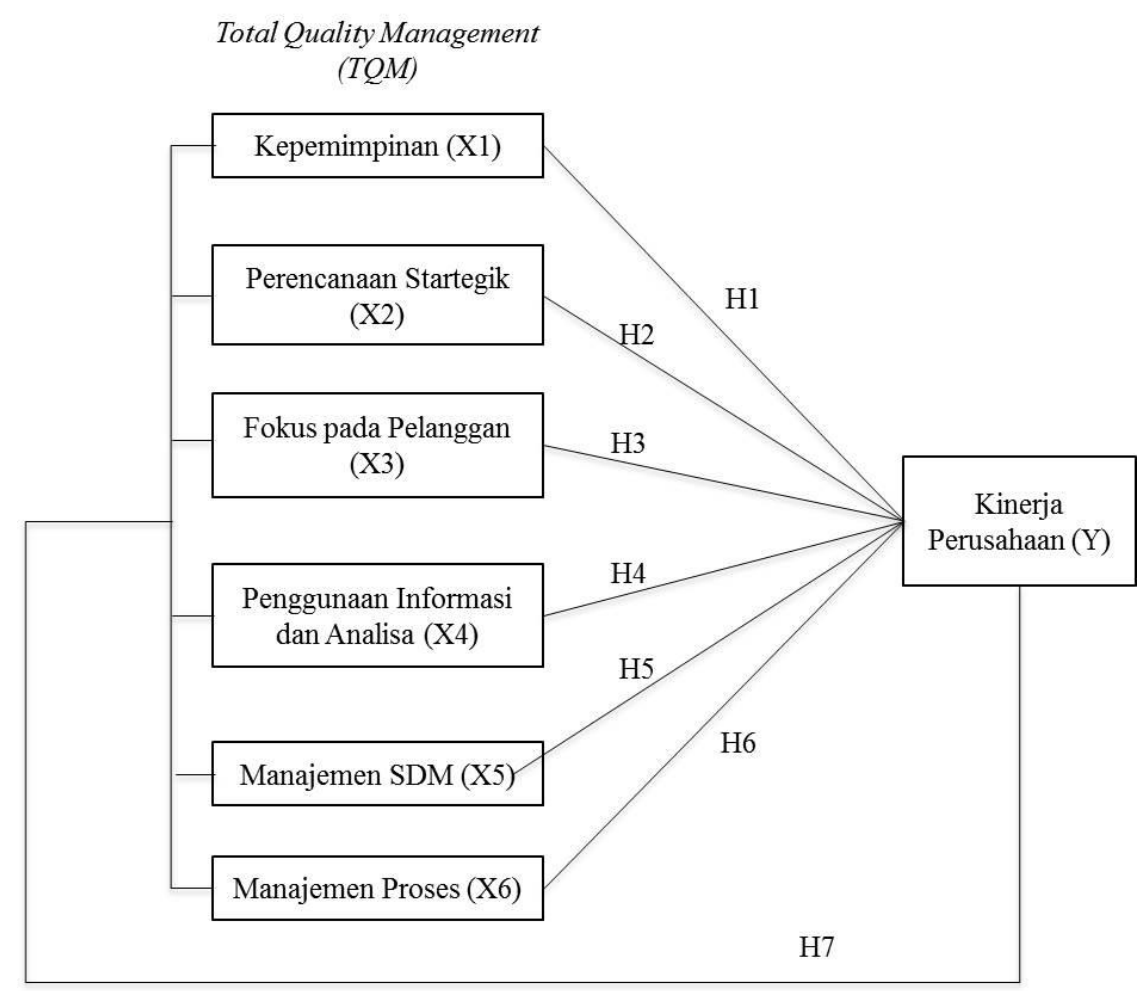

H1: Kepemimpinan berpengaruh signifikan terhadap Kinerja Perusahaan

H2: Perencanaan Strategik berpengaruh signifikan terhadap Kinerja Perusahaan

H3: Fokus pada Pelanggan berpengaruh signifikan terhadap Kinerja Perusahaan

H4: Penggunaan Informasi dan Analisa berpengaruh signifikan terhadap Kinerja Perusahaan

H5:Manajemen SDM berpengaruh signifikan terhadap Kinerja Perusahaan

H6: Manajemen Proses berpengaruh signifikan terhadap Kinerja Perusahaan 
H7: Kepemimpinan, Perencanaan Strategik, Fokus pada Pelanggan , Penggunaan Informasi dan Analisa, Manajemen SDM dan Manajemen Proses secara bersama-sama berpengaruh signifikan terhadap kinerja perusahaan

\section{METODOLOGI PENELITIAN}

Penelitian ini mengumpulkan data dengan menyebarkan kuesioner yang dibagikan ke para manajer, staff dan bagian produksi yang bekerja di PT XYZ dengan jumlah 176 orang. Kriteria responden merupakan karyawan yang memiliki masa kerja minimal 1 tahun dengan anggapan responden sudah mengetahui sistem operasional perusahaan secara umum.

Data primer dalam penelitian ini diperoleh dengan menggunakan kuesioner penelitian yang disebar secara langsung. Dalam penelitian ini, data yang telah terkumpul dari hasil kuesioner yang telah dijawab oleh responden akan diolah secara statistik dengan menggunakan metode analisis regresi berganda. Sebelumnya, dilakukan uji instrumen pengumpulan data dan uji asumsi klasik terlebih dahulu untuk menilai kelayakan data yang digunakan dalam penelitian ini.

Penelitian ini bersifat kuantitatif dan menggunakan analisis regresi berganda dengan menganalisis faktor-faktor TQM (Kepemimpinan, Perencanaan Strategik, Fokus pada Pelanggan, Penggunaan Informasi dan Analisa, Manajemen SDM dan Manajemen Proses) terhadap Kinerja Perusahaan. Persamaan regresi linear berganda dalam penelitian ini adalah sebagai berikut:

Kinerja Perusahaan $=\alpha+\beta 1$.Kepemimpinan $+\beta 2$.Perencanaan Strategik $+\beta 3$.Fokus pada Pelanggan $+\beta 4$.Penggunaan Informasi dan Analisa $+\beta 5$.Manajemen SDM $+\beta 6$. Manajemen Proses $+\varepsilon$

\section{HASIL}

Berikut merupakan hasil dari penelitian mengenai analisis pengaruh faktor-faktor TQM terhadap kinerja perusahaan.

\section{Hasil Uji Validitas}

Tabel 1. Hasil Uji Validitas

\begin{tabular}{|c|c|c|c|c|}
\hline Variabel & Indikator & r Hitung & r Tabel & Keterangan \\
\hline \multirow[t]{5}{*}{ Kepemimpinan } & $\mathrm{X} 1.1$ & 0,575 & 0,1480 & Valid \\
\hline & $\mathrm{X} 1.2$ & 0,546 & 0,1480 & Valid \\
\hline & $\mathrm{X} 1.3$ & 0,555 & 0,1480 & Valid \\
\hline & $\mathrm{X} 1.4$ & 0,547 & 0,1480 & Valid \\
\hline & $\mathrm{X} 1.5$ & 0,445 & 0,1480 & Valid \\
\hline \multirow[t]{5}{*}{ Perencanaan Strategik } & $\mathrm{X} 2.1$ & 0,561 & 0,1480 & Valid \\
\hline & $\mathrm{X} 2.2$ & 0,688 & 0,1480 & Valid \\
\hline & $\mathrm{X} 2.3$ & 0,632 & 0,1480 & Valid \\
\hline & $\mathrm{X} 2.4$ & 0,660 & 0,1480 & Valid \\
\hline & $\mathrm{X} 2.5$ & 0,527 & 0,1480 & Valid \\
\hline \multirow[t]{5}{*}{ Fokus Pada Pelanggan } & $\mathrm{X} 3.1$ & 0,330 & 0,1480 & Valid \\
\hline & $\mathrm{X} 3.2$ & 0,498 & 0,1480 & Valid \\
\hline & X3.3 & 0,673 & 0,1480 & Valid \\
\hline & X3.4 & 0,575 & 0,1480 & Valid \\
\hline & $\mathrm{X} 3.5$ & 0,466 & 0,1480 & Valid \\
\hline Penggunaan Informasi dan & $\mathrm{X} 4.1$ & 0,710 & 0,1480 & Valid \\
\hline
\end{tabular}




\begin{tabular}{|c|c|c|c|c|}
\hline Variabel & Indikator & r Hitung & r Tabel & Keterangan \\
\hline \multirow[t]{4}{*}{ Analisa } & $\mathrm{X} 4.2$ & 0,839 & 0,1480 & Valid \\
\hline & $\mathrm{X} 4.3$ & 0,785 & 0,1480 & Valid \\
\hline & $\mathrm{X} 4.4$ & 0,805 & 0,1480 & Valid \\
\hline & $\mathrm{X} 4.5$ & 0,805 & 0,1480 & Valid \\
\hline \multirow[t]{5}{*}{ Manajemen SDM } & $\mathrm{X} 5.1$ & 0,569 & 0,1480 & Valid \\
\hline & $\mathrm{X} 5.2$ & 0,551 & 0,1480 & Valid \\
\hline & $\mathrm{X} 5.3$ & 0,697 & 0,1480 & Valid \\
\hline & $\mathrm{X} 5.4$ & 0,490 & 0,1480 & Valid \\
\hline & $\mathrm{X} 5.5$ & 0,595 & 0,1480 & Valid \\
\hline \multirow[t]{5}{*}{ Manajemen Proses } & X6.1 & 0,550 & 0,1480 & Valid \\
\hline & X6.2 & 0,672 & 0,1480 & Valid \\
\hline & X6.3 & 0,662 & 0,1480 & Valid \\
\hline & X6.4 & 0,756 & 0,1480 & Valid \\
\hline & X6.5 & 0,522 & 0,1480 & Valid \\
\hline \multirow[t]{5}{*}{ Kinerja Perusahaan } & Y1 & 0,548 & 0,1480 & Valid \\
\hline & Y2 & 0,603 & 0,1480 & Valid \\
\hline & Y3 & 0,486 & 0,1480 & Valid \\
\hline & Y4 & 0,578 & 0,1480 & Valid \\
\hline & Y5 & 0,243 & 0,1480 & Valid \\
\hline
\end{tabular}

Sumber: Hasil olahan data SPSS 23 (2018)

Hasil pengujian validitas menunjukkan bahwa seluruh pertanyaan dari masing-masing variabel memiliki nilai $r$ hitung lebih besar dari $r$ tabel ( $r$ hitung $>0,1480$ ). Hasil tersebut menunjukkan bahwa seluruh pertanyaan yang digunakan untuk mengukur variabel adalah valid dan dapat digunakan pada penelitian selanjutnya.

\section{Hasil Uji Reliabilitas}

Tabel 2. Hasil Uji Reliabilitas

\begin{tabular}{|l|l|l|l|}
\hline No & Variabel & $\begin{array}{l}\text { Cronbach's } \\
\text { Alpha }\end{array}$ & Keterangan \\
\hline 1 & Kepemimpinan & 0,762 & Reliabel \\
\hline 2 & Perencanaan Strategik & 0,820 & Reliabel \\
\hline 3 & Fokus Pada Pelanggan & 0,721 & Reliabel \\
\hline 4 & $\begin{array}{l}\text { Penggunaan Informasi dan } \\
\text { Analisa }\end{array}$ & 0,915 & Reliabel \\
\hline 5 & Manajemen SDM & 0,795 & Reliabel \\
\hline 6 & Manajemen Proses & 0,829 & Reliabel \\
\hline 7 & Kinerja Perusahaan & 0,724 & Reliabel \\
\hline
\end{tabular}

Sumber: Hasil olahan data SPSS 23 (2018)

Hasil uji reliabilitas pada tabel diatas, nilai cronbach's Alpha pada masing-masing variabel lebih besar dari 0,70, sehingga dapat disimpulkan bahwa seluruh variabel adalah reliabel.

Hasil Uji Normalitas 
Berdasarkan Gambar 1, terlihat bahwa titik - titik menyebar di sekitar garis diagonal dan mengikuti garis diagonal, hal ini menunjukkan bahwa model regresi normal dan layak dipakai untuk memprediksi variabel bebas.

\section{Gambar 1. Hasil Uji Normalitas}

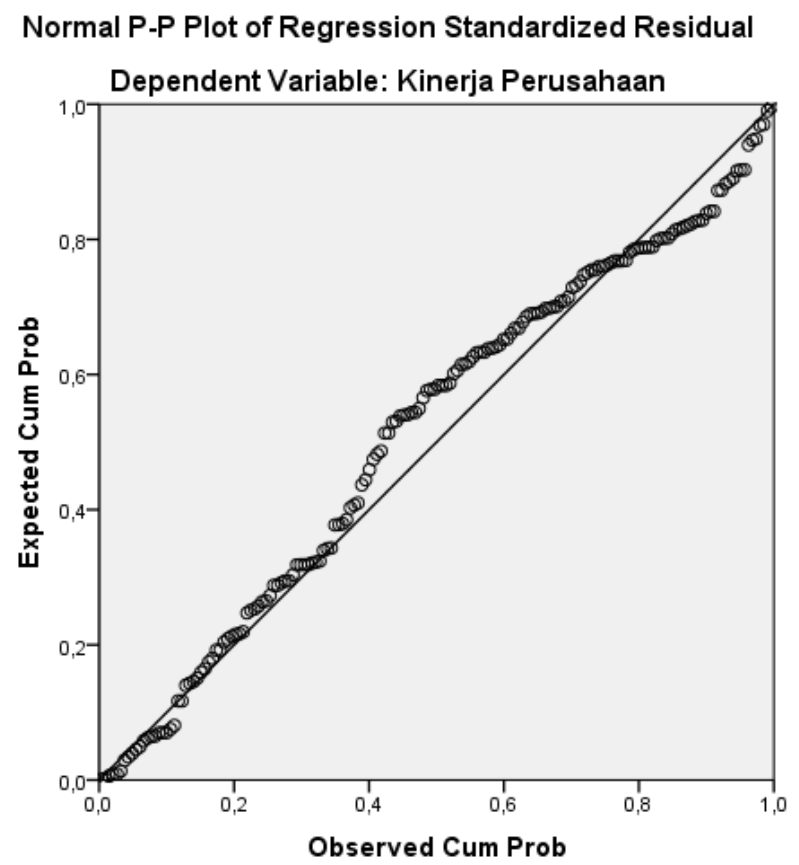

Sumber: Hasil olahan data SPSS 23 (2018)

\section{Hasil Uji Multikolinieritas}

Berdasarkan hasil pengujian multikolinearitas, diketahui bahwa seluruh variabel independen yang diuji terbebas dari masalah multikolinearitas. Hal tersebut dapat dilhat dari nilai Tolerance dari ke enam variabel independen tersebut $>0,10$ dan nilai VIF $<10$. Hasil menunjukkan tidak terjadi korelasi antara variabel independen.

Tabel 4. Uji Multikolinearitas

\begin{tabular}{|c|c|c|c|}
\hline \multicolumn{2}{|c|}{ Model } & \multicolumn{2}{c|}{ Collinearity Statistics } \\
\cline { 3 - 4 } & (Constant) & Tolerance & VIF \\
\hline \multirow{4}{*}{1} & X1 & 0,287 & 3,482 \\
\cline { 2 - 4 } & X2 & 0,750 & 1,334 \\
\cline { 2 - 4 } & X3 & 0,296 & 3,381 \\
\cline { 2 - 4 } & X4 & 0,607 & 1,649 \\
\cline { 2 - 4 } & X5 & 0,408 & 2,451 \\
\cline { 2 - 4 } & X6 & 0,329 & 3,042 \\
\cline { 2 - 4 } & &
\end{tabular}

Sumber: Hasil olahan data SPSS 23 (2018)

\section{Hasil Uji Heteroskedastisitas}

Berdasarkan Gambar 2, terlihat bahwa titik - titik menyebar dengan membentuk pola yang acak, sehingga dapat disimpulkan bahwa pada model regresi tidak terjadi masalah Heteroskedastisitas (Hair, 2010). 
Gambar 2. Hasil Uji Heteroskedastisitas

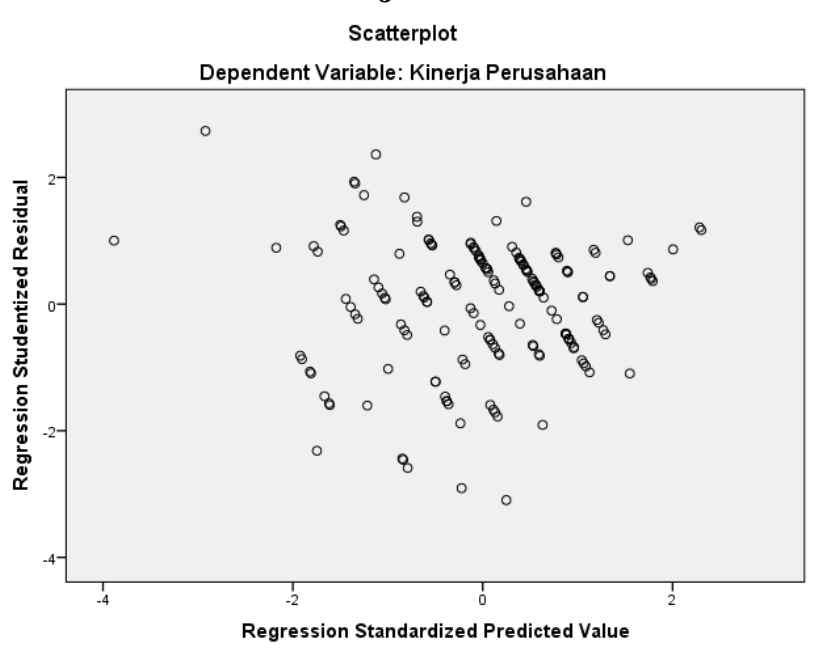

Sumber: Hasil olahan data SPSS 23 (2018)

\section{Hasil Analisis Regresi Linier Berganda}

\section{Tabel 5. Regresi Berganda}

\begin{tabular}{|c|c|c|c|}
\hline \multicolumn{2}{|c|}{ Model } & $B$ & Sig. \\
\hline \multirow{4}{*}{1} & (Constant) & 0,952 & 0,128 \\
\cline { 2 - 4 } & X1_Kepemimpinan & 0,476 & $0,000^{* * *}$ \\
\cline { 2 - 4 } & X2_Perencanaan Strategik & 0,023 & 0,441 \\
\cline { 2 - 4 } & X3_Fokus Pada Pelanggan & 0,224 & $0,000^{* * *}$ \\
\cline { 2 - 4 } & X4_Penggunaan Informasi dan Analisa & 0,014 & 0,540 \\
\hline & X5_Manajemen SDM & 0,079 & $0,043^{* *}$ \\
\hline \multirow{2}{*}{ X6_Manajemen Proses } & 0,153 & $0,004^{* * *}$ \\
\hline \multirow{2}{*}{ F } & 169,337 & $0,000^{* * *}$ \\
\hline & 0,852 & \\
\hline \multirow{2}{*}{$R^{2}$} & & \\
\hline
\end{tabular}

*** Signifikan pada $\alpha 0,01$

** Signifikan pada $\alpha 0,05$

* Signifikan pada $\alpha 0,10$

Tabel 5 menunjukkan bahwa variabel Kepemimpinan, Fokus Pada Pelanggan, Manajemen SDM dan Manajemen Proses berpengaruh signifikan terhadap Kinerja Perusahaan karena memperoleh nilai signifikan lebih kecil dari 0,05. Sedangkan, variabel Perencanaan Strategik dan Penggunaan Informasi \& Analisa tidak berpengaruh signifikan terhadap Kinerja Perusahaan karena memperoleh nilai signifikan lebih besar dari 0,05.

Nilai F-hitung sebesar 169,337. Nilai F-tabel pada Tabel Statistik dengan level 5\%, nilai df $1(\mathrm{k}-1)$ bernilai 6 dan df $2(\mathrm{n}-\mathrm{k})$ bernilai 169, maka didapatkan nilai F-tabel sebesar 2,15. Nilai F-hitung $(169,337)$ lebih besar daripada nilai F-tabel $(2,15)$, maka maka Ha diterima dan Ho ditolak. Hal ini berarti variabel kepemimpinan, perencanaan strategik, fokus pada pelanggan, penggunaan informasi dan analisa, manajemen SDM dan manajemen proses secara bersama - sama berpengaruh terhadap kinerja perusahaan.

Hasil uji koefisien determinasi $\left(\mathrm{R}^{2}\right)$ pada kolom nilai adjusted $\mathrm{R}$ square adalah 0,852 atau sebesar 85,2\%. Dengan demikian dapat disimpulkan bahwa variabel X1(kepemimpinan), X2 (perencanaan strategik), X3 (fokus pada pelanggan), X4 (penggunaan informasi dan analisa), X5 (manajemen SDM) dan X6 (manajemen proses) 
secara bersama-sama mempengaruhi variabel $\mathrm{Y}$ (kinerja perusahaan) sebesar 85,2\%. Sedangkan sisanya, 14,8\% dipengaruhi oleh variabel diluar model penelitian. Dari tabel 5 didapat persamaan akhir sebagai berikut:

$$
\mathrm{KP}=0,952+0,476 \mathrm{~K}+0,023 \mathrm{PS}+0,224 \mathrm{FP}+0,014 \mathrm{PI}+0,079 \mathrm{MS}+0,153 \mathrm{MP}
$$

\section{KESIMPULAN}

Berdasarkan berbagai pengujian dan analisis yang telah dilakukan dari penelitian ini diperoleh beberapa kesimpulan mengenai pengaruh Total Quality Management (TQM) terhadap kinerja perusahaan antara lain

1. Variabel kepemimpinan, fokus pada pelanggan, manajemen SDM , dan manajemen proses berpengaruh signifikan secara parsial terhadap kinerja perusahaan. Sementara itu, variabel informasi \& analisa dan perencanaan strategik tidak berpengaruh signifikan secara parsial terhadap kinerja perusahaan.

2. Variabel kepemimpinan, perencanaan strategik, fokus pada pelanggan, Penggunaan informasi dan analisa, manajemen SDM, dan manajemen proses secara bersamasama berpengaruh terhadap variabel kinerja perusahaan.

3. Variabel kepemimpinan merupakan variabel dominan dalam mempengaruhi variabel kinerja perusahaan.

\section{DAFTAR PUSTAKA}

Flynn, Barbara B., Roger G. Schroeder.,dan Sadao Sakakibara.(1994). "A Framework for quality management research and an associated measurement instrument". Journal of Operations Management 11. Hal 339-366. Lowa State University. USA.

Jaafreh \& Al-abedallat.(2013).The Effect of Quality Management Practices on Organizational Performance in Jordan: An Empirical Study.

Prajogo, Daniel,I.,and Brown,A.(2004). The Relationship Between TQM Practice and Quality Performance and the Role of Formal TQM Programs: An Australian Empirical Study. Quality Management Journal,11(4),31-42.

Tjiptono, Fandy dan Anastasia Diana.(2012). Total Quality Manajemen. Edisi Revisi. Andy: Yogyakarta

Ahmad, M.F, Zakuan, N, Jusoh, A. , Yusof, S.M , MNN Hisyamudin, and Takala, J.(2013). "The Relationships Between The Extent of TQM Practices and The Importance on Business Performance: A Survey in Malaysia”. Proceedings of the 2nd International Conference on Advanced Manufacturing. University Tun Hussein Onn,MALAYSIA.

Hassan, Masood Ul., Muhammad Saqib Nawaz.,Sadia Shaukat., dan Saad Hassan.(2014). "AnEmpirical Assessment of TQM Dimensions and Their Relationship with Firm Performance: Evidence from the Textile Sector of Pakistan". World Applied Sciences Journal 30 (6): 696-705, Bahauddin Zakariya University, Multan, Pakistan.

Samson, Danny., dan Mile Terziovski.(1999). "The relationship between total quality management practices and operational performance". Journal of Operations Management 17, hal 393- 409. Department of Management, Unilersity of Melbourne, Australia.

Saraph, J. V., Benson, P. G. dan Schroeder, R. G. (1989) 'An instrument for measuring the critical factors of quality management'. Decision Sciences, Vol.20, No.4, pp.810-829. 
